\title{
PENGARUH TINGKAT KEKERINGAN TERHADAP PERTUMBUHAN GENERATIF KULTIVAR KACANG TUNGGAK (Vigna unguiculata L)
}

\section{(The influence of drought level on generative growth of cowpea cultivars (Vigna unguiculata L)}

\author{
Zulipah Mahdalena \\ Prodi Agribisnis Fakultas Pertanian Universitas Achmad Yani Banjarmasin \\ Email: sz.mahdalena@gmail.com
}

Article Submitted: 05-09-2020

Article Accepted : 23-09-2020

\begin{abstract}
This study aims to determine the effect of the interaction between cowpea cultivars and level of water dryness. This Research is a field experiment, which is arranged for a randomized block design, with two factors, cowpea cultivar and level of water dryness. Cowpea cultivars contents of ten levels, that is Arab, Kuning, Papan, Padi, KT -1, KT-2, KT-4, KT-6, KT-7, KT8, and Level of water dryness content of $100 \%$ field capacity, $65 \%$ field capacity, and $30 \%$ field capacity. The Parameters observed were the age of the plant to start flowering, the dry weight of the upper plant, the number of pods per plant, the number of pods contained in each plant. The results showed that the level of water dryness affected the dry seed weight of the plant, the age at which flowering began, the number of pods contained in the plant, and the dry weight of the upper plants. The interaction between the level of water dryness and cultivar had a significant effect on the number of pods plants, whereas cultivars affect the sucrose content.
\end{abstract}

Keywords: cowpea, cultivars, levels of water dryness.

\section{PENDAHULUAN}

Kacang tunggak (Vigna unguiculata L) merupakan tanaman setahun yang tumbuh merambat, buahnya berbentuk polong dengan biji berbentuk bulat panjang, berwarna merah tua, hitam atau putih dan mempunyai kelekukan ditengahnya (andarwulan dan Hariyadi,2005). Selain toleran terhadap kekeringan, kacang tunggak juga mampu mengikat nitrogen dari udara. Potensi hasil kacang tunggak cukup tinggi yaitu mencapai 1,5 - 2 ton/ha. (Balitkabi, 2006). Kacang tunggak berpotensi sebagai sumber protein nabati .

Kadar protein kacang tunggak setara dengan kacang hijau atau kacang gude. Bahkan kadar vitamin B1 nya lebih tinggi dibandingkan dengan kacang hijau, dan memiliki kadar asam amino metionin yang tinggi. Secara umum konsumsi protein penduduk Indonesia termasuk kurang, maka perlu upaya meningkatkan bahan pangan sumber protein. Jenis kacang kacangan potensial dikembangkan menjadi produk yang bergizi dan sesuai selera masyarakat (Handajani, 1994).

Salah satu upaya yang penting untuk meningkatkan produksi tanaman kacang kacangan yang merupakan salah satu sumber protein nabati adalah dengan perluasan areal tanam pada lahan kering yang dominan di Kalimantan Selatan. Kendala yang terpenting pada lahan kering adalah menyangkut ketersediaan air pada musim kemarau, yang sering menyebabkan cekaman kekeringan. Penelitian Taufik Rizal (2004), melaporkan bahwa dari 3 kultivar kacang Nagara dan 2 kultivar kacang tunggak menunjukan perbedaan tanggapan terhadap kekeringan. Kultivar 
kuning dan KT-7 adalah kultivar yang paling cocok dibuddidayakan dilahan kering, dan kultivar KT-6 adalah yang paling toleran trhadap kekeringan.

Penelitian ini bertujuan untuk mengetahui pengaruh interaksi antara kultivar dengan tingkat cekaman air terhadap hasil tanaman kacang tunggak, dan mencari kultivar terbaik yang tahan terhadap cekaman air.

\section{METODE PENELITIAN}

\section{Tempat dan waktu}

Penelitian ini dilakukan dirumah kaca bertempat di jalan Unlam II Banjarbaru, sedangkan analisis laboratorium dilakukan di laboratorium jurusan Budidaya Pertanian Fakultas Pertanian ULM dan Laboratorium Jurusan MIPA ULM . Waktu Penelitian mulai bulan Agustus 2018 sampai dengan Januari 2019.

\section{Metode Penelitian}

Penelitian ini adalah percobaan lapangan dengan Rancangan Penelitian RAK (Rancangan Acak Kelompok) dengan 2 (dua) faktor dan 2 (dua) ulangan. Faktor yang diteliti adalah 3 (tiga) tingkat kekeringan $(100 \%, 65 \%$ dan $30 \%)$ dan 10 kultivar kacang tunggak yaitu kultivar Arab, kuning, Papan, Padi, KT-1, KT-2, KT-4, KT-6, KT-7 Dan KT-8. Dengan 30 kombinasi perlakuan dan 2 ulangan sehingga diperoleh 60 satuan percobaan.

\section{Pengamatan :}

Variabel-variabel yang diamati adalah : umur tanaman mulai berbunga, bobot kering tanaman bagian atas, jumlah polong, jumlah polong isi, bobot biji kering, indeks panen, dan kandungan sukrosa.

\footnotetext{
Analisis data

Model linier Aditif yang dipostulatkan : Yijk $=\mu+\mathrm{k}+\mathrm{i}+(\alpha \beta) \mathrm{ij}+€ \mathrm{ijk}$ Keterangan : $\mathrm{I}=1,2,3$ (cekaman air)
}

$$
\begin{aligned}
\mathrm{J}= & 1,2,3,4,5,6,7,8,9,10 \text { (kultivar) } \\
\mathrm{K}= & \text { kelompok } \\
\mathrm{Yijk}= & \text { hasil pengamatan satuan percobaan } \\
& \text { yang mendapat perlakuan taraf } \\
& \text { ke- } \mathrm{i} \text { dari faktor A dan taraf ke- } \mathrm{j} \\
& \text { dari faktor } \\
\mu= & \text { nilai tengah umum } \\
{ }_{\delta} \mathrm{k}= & \text { pengaruh kelompok ke-k } \\
\mathrm{ai}= & \text { pengaruh tingkat kekeringan air ke-i } \\
\beta \mathrm{j}= & \text { pengaruh kultivar pada taraf ke- } \mathrm{j} \\
(\alpha \beta) \mathrm{ij}= & \text { pengaruh interaksi AB pada taraf } \\
& \text { ke-i (dari faktor A) dan taraf ke-j } \\
& \text { (dari faktor B) }
\end{aligned}
$$

$\sum \mathrm{ijk}=$ pengaruh acak pada taraf ke-i (dari faktor A), taraf ke-j (dari faktor B) dan interaksi $A B$ yang ke-i dan kej, serta pada kelompok ke-k

Selanjutnya dibentuk analisis ragam, untuk mengetahui perbedaan pengaruh perlakuan terhadap peubah yang diamati menggunakan uju $\mathrm{F}$ pada taraf nyata $5 \%$, apabila berpengaruh nyata maka dilanjutkan uji jarak berganda Duncan (DMRT) pada taraf $5 \%$.

Jika perlakuan A atau B saja yang berpengaruh nyata atau sangat nyata makan analisis dilanjutkan dengan uji beda nilai tengah (BNT) pad taraf $5 \%$.

(Sugiyono, 2008)

\section{HASIL DAN PEMBAHASAN}

\section{Umur tanaman mulai berbunga}

Umur pengaruh mulai berbunga dipengaruh secara nyata oleh cekaman air. Rata-rata umur tanaman mulai berbunga yang mendapat pengaruh cekaman air disajikan pada Tabel 1 dibawah ini. Dari tabel 1 menunjukan bahwa cekaman air sampai dengan $65 \%$ kapasitas lapang tidak mempengaruhi umur tanaman mulai berbunga, tetapi jika cekaman bertambah menjadi $30 \%$ kapasitas lapang, maka akan berpengaruh secara signifikan terhadap umur tanaman mulai berbunga, sehingga umur tanaman mulai berbunga semakin lama. 
Tabel 1. Pengaruh kekeringan terhadap umur tanaman mulai berbunga dan bobot kering tanaman bagian atas

\begin{tabular}{lcccc}
\hline \multicolumn{2}{c}{ Nilai Tengah } & \multicolumn{3}{c}{ Tingkat Kekeringan (\%) } \\
\cline { 2 - 5 } & mulai & $38,90 \mathrm{~b}$ & 65 & 30 \\
\hline $\begin{array}{l}\text { Umur tanaman } \\
\text { berbunga (mst) }\end{array}$ & & $38,20 \mathrm{~b}$ & $43,80 \mathrm{a}$ \\
Bobot kering (gr) & $24,39 \mathrm{~b}$ & $19,41 \mathrm{~b}$ & $9.22 \mathrm{a}$ \\
\hline
\end{tabular}

Keterangan : Nilai tengah diikuti huruf yang sama pada kolom yang sama tidak berbeda nyata berdasarkan uji BNJ $5 \%$.

Hal tersebut pada saat permulaan fase pembungaan tanaman sangat sensitif terhadap cekaman air sehingga menunda inisiasi bunga, seperti yang dilansir dari Tohari dan Soedharoedjian (1984), bahwa secara umum tanaman mulai berbunga dipengaruhi oleh fotoperiodisitas, suhu dan cekaman air, sehingga menunda inisiasi bunga.

Kandungan air dalam jaringan meristem yang rendah berhubungan dengan kebutuhan air untuk pengembangan sel, hal ini menyebabkan pengurangan sintesa, protein diding sel dan pengembangan sel. Tingkat kekeringan juga memyebabkan turunnya tekanan Turgor sel sehingga perkembangan daun muda terhambat karena terjadi pengerutan sel. Berkurangnya luas daun akibat pengerutan sel menyebabkan berkurangnya absorbsi cahaya yang diterima daun yang berperan penting fotosintesa, sehingga laju fotosintesa menjadi lambat, secara nyata juga akan menurunkan produktivitas tanaman (Nurhidayati, Rina Laksmi H, Arie Triana dan Sudjino, 2017).

\section{Bobot kering bagian atas tanaman}

Cekaman air berpengaruh secara nyata terhadap bobot kering tanaman bagian atas pada umur $7 \mathrm{mst}$ dan saat panen, seperti pada Tabel 1. Pada umur 7 mst dan saat panen, mengindikasikan hal yang sama, yaitu peningkatan cekaman air sampai 100 $\%$ ke $65 \%$ kapasitas lapang tidak menyebabkan penurunan secara signifikan terhadap bobot kering tanaman bagian atas. Namun apabila cekaman air dinaikan lagi menjadi $30 \%$ kapasitas lapang, maka terjadi penurunan bobot kering bagian atas tanaman secara signifikan.

Tabel 2. Pengaruh kultivar dan tingkat kekeringan terhadap jumlah polong per tanaman

\begin{tabular}{lccc}
\hline \multirow{2}{*}{ Kultivar } & \multicolumn{3}{c}{ tingkat kekeringan Air (\%) } \\
\cline { 2 - 4 } & 100 & 60 & 30 \\
\hline Kuning & $10.50 \mathrm{q}$ & $6.00 \mathrm{j}$ & $2.00 \mathrm{~b}$ \\
Papan & $10.00 \mathrm{p}$ & 7.501 & $6.50 \mathrm{k}$ \\
Padi & $9.00 \mathrm{n}$ & $11.00 \mathrm{r}$ & $2.00 \mathrm{~b}$ \\
KT-1 & $6.50 \mathrm{n}$ & $5.00 \mathrm{~h}$ & $5.00 \mathrm{~h}$ \\
KT-2 & $5.00 \mathrm{~h}$ & $5.50 \mathrm{i}$ & $2.25 \mathrm{c}$ \\
KT-4 & $8.00 \mathrm{~m}$ & $6.50 \mathrm{k}$ & $2.00 \mathrm{~b}$ \\
KT-6 & $9.50 \mathrm{~h}$ & $4.00 \mathrm{f}$ & $3.50 \mathrm{c}$ \\
KT-7 & 7.501 & $4.50 \mathrm{~g}$ & $3.00 \mathrm{~d}$ \\
KT-8 & $9.50 \mathrm{o}$ & $9.00 \mathrm{n}$ & $3.00 \mathrm{~d}$ \\
\hline
\end{tabular}

Ket : Nilai tengah diikuti huruf sama tidak berbeda nyata berdasarkan uji BNJ $5 \%$.

Bobot kering tanaman berhubungan erat dengan penurunan laju fotosintesa.
Tingkat kekeringan yang tinggi menyebabkan penyerapan hara dan suplay 
air yang dibutuhkan untuk pertumbuhan tidak terpenuhi, akibatnya pertumbuhan generatif menjadi terhambat. Hal ini ditunjukan dengan berkurangnya bobot kering tanaman (Nurhidayati, Rina Laksmi Hendrati, Arie Triana dan Sudjino, 2017).

\section{Jumlah Polong Pertanaman}

Interaksi tingkat kekeringan air dan kultivar berpengaruh secara nyata terhadap jumlah polong pertanaman. Jumlah polong pertanaman tertinggi pada tingkat kekeringan $30 \%$ ditunjukan oleh kultivar Papan.

\section{Jumlah polong isi dan bobot biji kering per tanaman}

Jumlah polong isi pertanaman hanya dipengaruhi secara nyata oleh tingkat kekeringan air. Rata-rata jumlah polong isi yang mendapat pengaruh madiri cekaman seperti pada Tabel 3 .

Tabel 3. Pengaruh tingkat kekeringan air terhadap jumlah polong isi pertanaman

\begin{tabular}{lccc}
\hline \multirow{2}{*}{ Nilai Tengah } & \multicolumn{3}{c}{ Tingkat Kekeringan (\%) } \\
\cline { 2 - 4 } & 100 & 65 & 30 \\
\hline Jumlah polong isi & $4.70 \mathrm{~b}$ & $3.10 \mathrm{~b}$ & $1.30 \mathrm{a}$ \\
pertamanan (biji) & & & $3.64 \mathrm{a}$ \\
Bobot biji kering (gr) & $9.46 \mathrm{c}$ & $7.45 \mathrm{~b}$ & .
\end{tabular}

Keterangan : Nilai tengah diikuti huruf yang sama pada kolom yang sama tidak berbeda nyata berdasarkan uji BNJ $5 \%$.

Peningkatan kekeringan air sampai $30 \%$ menunjukan penurunan secara signifikan terhadap jumlah polong isi pertanaman. Sedangkan bobot biji kering pertanaman dipengaruhi secara nyata oleh tingkat kekeringan dan kultivar secara mandiri, seperti disajikan dalam Tabel 3.

Peningkatan kekeringan menyebabkan penurunan terhadap bobot biji kering pertanaman, bobot biji kering lebih sensitif terhadap tingkat kekeringan, karena langsung mengalami penurunan secara signifikan, hal ini diduga karena peningkatan kekeringan air mengakibatkan kurangnya $\mathrm{CO} 2$ yang masuk kemesofil daun yang diakibatkan oleh menutupnya stomata, sehingga fotosintat yang dihasilkan untuk pengisian biji lebih sedikit.

Tingkat kekeringan yang semakin tinggi selama periode pengisian polong menyebabkan penurunan laju fotosintesis akaibat penutupan stomata dan penurunan transpor elektron dan kapasitas fofforilasi dalam kloroplas (Dolly Saputra, Paul B.Timotiwu dan Ermawati, 2015).

Peningkatan kekeringan menyebabkan penurunan terhadap bobot biji kering pertanaman, bobot biji kering lebih sensitif terhadap tingkat kekeringan, karena langsung mengalami penurunan secara signifikan,hal ini diduga karena peningkatan kekeringan air mengakibatkan kurangnya $\mathrm{CO} 2$ yang masuk kemesofil daun yang diakibatkan oleh menutupnya stomata, sehingga fotosintat yang dihasilkan untuk pengisian biji lebih sedikit. Respon masing masing kultivar terhadap bobot biji kering berbeda, kultivar Arab menunjukan bobot biji kering pertanaman tertinggi $(8,49$ gr) sedangkan kultivar KT-2 menghasilkan bobot biji kering pertanaman terendah $(5,52$ gr), seperti ditunjukan pada tabel 4 . 
Tabel 4. Pengaruh kultivar terhadap bobot biji kering per tanaman dan Indeks panen

\begin{tabular}{lcc}
\hline Kultivar & \multicolumn{2}{c}{ Nilai Tengah } \\
\hline Arab & Bobot biji kering per tanaman $(\mathrm{gr})$ & Indeks Panen \\
Kuning & $8.49 \mathrm{~h}$ & $0.52 \mathrm{f}$ \\
Papan & $7.18 \mathrm{f}$ & $0.36 \mathrm{~b}$ \\
Padi & $7.40 \mathrm{~g}$ & $0.44 \mathrm{c}$ \\
KT-1 & $6,32 \mathrm{c}$ & $0.37 \mathrm{~b}$ \\
KT-2 & $6,21 \mathrm{c}$ & $0.42 \mathrm{c}$ \\
KT-4 & $5.52 \mathrm{a}$ & $0.28 \mathrm{a}$ \\
KT-6 & $5,97 \mathrm{~b}$ & $0.38 \mathrm{bc}$ \\
KT-7 & $6.91 \mathrm{c}$ & $0.46 \mathrm{c}$ \\
KT-8 & $6.56 \mathrm{~d}$ & $0.42 \mathrm{c}$ \\
\hline Ket & $6.56 \mathrm{~d}$ & $0.44 \mathrm{c}$ \\
\hline
\end{tabular}

Ket : Nilai tengah diikuti huruf sama tidak berbeda nyata berdasarkan uji Duncan $5 \%$

Jumlah polong isi pertanaman, dan bobot biji kering pertanaman ditentukan oleh asimilasi potosintat pada bagian ini dan tergantung pada masa pengisian biji dan jumlah sel yang terbentuk dalam bji (Sitompul dan Guritno, 1995).

Menurut Tohati dan Soedharoedjin (1992), kenaikan bobot biji merupakan hasil pembesaran sel dan penimbun pati atau minyak atau keduanya pada lamanya periode pengisian biji efektif dan laju pertumbuhan biji. Bobot biji kering pada kondisi optimum lebih tinggi disebabkan karena peranan air dalam proses biokimia sel, biosintesa protein dan klorofil dan mempengaruhi asimilasi $\mathrm{CO} 2$ dalam tanaman.

\section{Indeks Panen}

Indeks panen adalah perbandingan antara hasil tanaman dengan bobot kering total tanaman. Indeks panen dipengaruhi secara nyata oleh perlakuan kultivar kacang tunggak, yang diperlihatkan seperti pada Tabel 4. Dari Tabel 4, indeks panen yang tertinggi dihasilkan oleh kultivar Arab $(0,52)$, sedangkan indeks panen yang paling rendah dihasilkan oleh kultivar KT-2 $(0,28)$, Hal ini diduga kultivar Arab adalah kultivar yang lebih toleran dan punya mekanisme adaptasi lingkungan yang lebih baik dibandingkan kultivar lainnya. Mekanisme adaptasi ini melibatkan kinerja asam absisat (ABA) yang memberi sinyal dari akar terus melalui pembuluh xylem dan terlibat dalam regulasi stomata selama tanaman mengalami cekaman air. Okumulasi ABA pada daun menyebabkan menyempitnya atau menutupnya stomata yang akan menurunkan laju transpirasi untuk menghindari kehilangan air Sel Tanaman.(Novita Anggraini, Eny Faridah dan Sapto Indrioko, 2015).

Di lansir juga dari Sitompul dan Guritno (1995), bahwa nilai indeks panen dipengaruhi oleh kultivar, hormon, suhu dan cahaya. Keempat faktor tersebut berpengaruh terhadap metabolisme secara keseluruhan terutama pada fase generatif dan berdampak pada indeks panen

Menurut Guritno dkk (1995), nilai indeks panen dipengaruhi oleh kultivar, hormon, suhu dan cahaya. Keempat faktor tersebut berpengaruh terhadap metabolisme secara keseluruhan terutama pada fase generatif dan berdampak pada indeks panen.

\section{Kandungan Sukrosa}

Kandungan sukrosa saat panen dipengaruhi secara nyata oleh kultivar dan tingkat kekeringan secara mandiri. Seperti pada Tabel 5 dan Tabel 6 . 
Tabel 5. Pengaruh kultivar terhadap kandungan sukrosa

\begin{tabular}{lc}
\hline Kultivar & Nilai tengah kandungan sukrosa $(\mathrm{gr})$ \\
\hline Arab & $6.29 \mathrm{dc}$ \\
Kuning & $8.12 \mathrm{f}$ \\
Papan & $5.68 \mathrm{c}$ \\
Padi & $4.14 \mathrm{~b}$ \\
KT-1 & $6.73 \mathrm{f}$ \\
KT-2 & $3.25 \mathrm{a}$ \\
KT-4 & $6.43 \mathrm{def}$ \\
KT-6 & $6.12 \mathrm{~d}$ \\
KT-7 & $6.08 \mathrm{~cd}$ \\
KT-8 & $6.66 \mathrm{ef}$ \\
\hline
\end{tabular}

Ket : Nilai tengah diikuti huruf sama tidak berbeda nyata berdasarkan uji Duncan $5 \%$

Tabel 6. Pengaruh tingkat kekeringan air terhadap kandungan sukrose

\begin{tabular}{rccc}
\hline \multirow{2}{*}{ Nilai Tengah } & \multicolumn{3}{c}{ Tingkat Kekeringan (\%) } \\
\cline { 2 - 4 } & 100 & 65 & 30 \\
\hline Kandungan sukrosa & $5.86 \mathrm{~b}$ & $6.39 \mathrm{c}$ & $4.06 \mathrm{a}$ \\
\hline
\end{tabular}

Ket : Nilai tengah diikuti huruf sama tidak berbeda nyata berdasarkan uji BNJ $5 \%$

Dari Tabel 5 kandungan sukrose paling tinggi ditunjukan oleh kultivar kuning $(8,12)$, walaupun tidak berbeda nyata dengan kultivar KT-1, KT-4 dan KT-8, dengan demikian kultivar kuning dapat dikatakan mempunyai kandungan solute yang lebih kental dibandingakan kultivar lain, Kandungan sukrose yang tinggi disebabkan meningkatnya aktivitas enzim amilase (Islami dan Utomo, 1995).

Dari Tabel 6, dapat dilihat bahwa apabila tingkat kekeringan air meningkat dari $100 \%$ menjadi $65 \%$ kandungan sukrose meningkat secara signifikan, tetapi apabila tingkat kekeringan ditingkatkan lagi menjadi $30 \%$ kandungan sukrose langsung turun secara signifikan. Hal ini diduga tanaman mempunyai batas toleransi hanya pada $65 \%$ kapasitas lapang. Dan apabila tingkat kekeringan ditingkatkan lagi maka mekanisme fisiologi dalam tanaman akan terganggu. Sehingga kandungan sukrose dalam phloem menurun draktis. Ketahanan tanaman secara umum terhadap tingkat kekeringan disebabkan oleh kemampuan protoplasma terhadap dehidrasi tanpa merubah struktur. Mekanisme yang terjadi adalah (1). Meningkatkan kemampuan akar untuk mengabsorbsi air (2). Mengurangi transpirasi (3). Meningkatkan efesiensi pemakaian air (Islami dan Utomo, 1995).

\section{KESIMPULAN}

1. Interaksi serta pengaruh mandiri tingkat kekeringan air dan kultivar menberkan pengaruh sangat nyata terhadap bobot keirng akar saat panen

2. Tingkat kekeringan air dan kultivar secara mandiri berpengaruh nyata terhadap bobot biji kering pertanaman, Tingkat Kekeringan air bepengaruh nyata terhadap umur mulai berbunga, jumlah polong isi pertanaman dan bobot kering tanaman bagian atas umur $7 \mathrm{mst}$ dan saat panen.

3. Interaksi tingkat kekeringan air dan kuktivar berpengaruh nyata terhadap jumlah polong pertanaman.

4. Kultivar berpengaruh nyata terhadap indeks panen dan kandungan sukrosa

5. Kultivar arab dan padi adalah kultivar yang mempunyai toleransi terhadap tingkat kekeringan air yang tinggi. 


\section{DAFTAR PUSTAKA}

Andarwulan dan Haryadi.2004. Optimasi Produksi antioksidan pada proses perkecambahan biji bijian dan disertifikasi produk pangan Fungsional dari kecambah yang dihasilkan. Laporan Penelitian .Institut Pertanian Bogor. Bogor.

Balitkabi. 2006. Diskripsi Varietas Kacang Tunggak (Vigna $s p$ ) . Balai Penelitian Tanaman Kacang kacangan dan Umbi umbian. Malang.

Dolly Saputra, Paul B.Timotiwu dan Ermawati, 2015. Pengaruh Cekaman kekeringan terhadap pertumbuhan dan produksi Benih lima Varietas Kedelai. Jurnal Agrotek Tropika/ISSN 23374993. Volume.3 No.1:7 - 13 Edisi Januari 2015.

Handajani. 1994. Pangan dan gizi .Universitas Sebelas Maret. Surakarta.

Nurhidayati, Rina Laksmi Hendrati, Arie Triana dan Sudjino, 2017. Pengaruh kekeringan terhadap Pertumbuhan dan Perkembangan Tanaman Nyamplung (Callophylum inophyllum L) dan Johar (Cassia florida vahl) dari pronenan yang berdeda. Jurnal Pemuliaan Tanaman Hutan/ISSN (E):
2527-8165, Volume 11 No.2 Edisi Desember 2017.

Novita Anggraini, Eny Faridah dan Sapto Indrioko. Pengaruh cekaman kekeringan terhadap prilaku fisiologis dan Pertumbuhan Bibit Black Locust (Robinia pseudoacacia). Jurnal Ilmu kehutanan ISSN (E) :2477-3751 Volume 9 No.1 Edisi Januari 2015.

Islami,T dan W.H.Utomo. 1995. Hubungan Tanah, air dan Tanaman. IKIP Semarang Press. Semarang.

Sitompul S.M dan B. Guritno. 1995. Analisis Pertumbuhan tanaman. Gajah mada university Press. Yogyakarta.

Sugiyono.2008 Metode Penelitian kuanttitatif, kualitatif dan $\mathrm{R}$ \& $\mathrm{D}$. Alfabeta . Bandung

Taufik Rizal. 2004. Studi ketahanan Genotipe Kacang Tuggak (Vigna unguiculata $L$ ) pada beberapa tingkat kekeringan. Skripsi. Fakultas Pertanian ULM. Banjarbaru.

Tohati dan Soedharoedjian. 1992. Fisiologi tanaman Budidaya Tropik. Diterjemahkan dari Petter R. Goldsworthy dan N.M. Fisher. Universitas Gajah Mada Press. Yogyakarta. 